\title{
Applied Anatomy of the Maxillofacial and Mandibular Regions of the Indian One-Humped Camel (Camelus dromedarius) and Its Clinical Implications during Regional Anesthesia
}

\author{
Anatomía Aplicada de las Regiones Maxilofaciales y Mandibulares del Camello Jorobado \\ (Camelus dromedarius) de la India y sus Implicaciones Clínicas durante la Anestesia Regional
}

\author{
O. P. Choudhary"; P. C. Kalita**; A. Kalita* \& P. J. Doley*
}

CHOUDhARY, O. P.; KALITA, P. C.; KALITA, A. \& DOLEY, P. J. Applied anatomy of the maxillofacial and mandibular regions of the Indian one-humped camel (Camelus dromedarius) and its clinical implications during regional anesthesia. Int. J. Morphol., 34(3) 968-974, 2016.

SUMMARY: Since there is a lack of comprehensive data on the applied anatomy of the head region of Indian one-humped camel and its clinical value during regional anesthesia; therefore, this study was designed to provide information on clinically important parameters and landmarks of the head region. This study involved some osteometric parameters of the maxillas and mandibles of six adult Indian one-humped camels without any apparent skeletal disorders. Then, a total of twenty one head measurements and indices were recorded in the present study. The supraorbital foramen distance, infraorbital foramen distance, skull length, skull width, cranial length, nasal length and skull width of the Indian one-humped camels were $6.35 \pm 0.047 \mathrm{~cm}, 8.41 \pm 0.076 \mathrm{~cm}, 48.75 \pm 0.244 \mathrm{~cm}, 22.66 \pm 0.108$ $\mathrm{cm}, 32.73 \pm 0.484 \mathrm{~cm}$ and $16.89 \pm 0.283 \mathrm{~cm}$, respectively. The skull index was $46.51 \pm 0.29 \mathrm{~cm}$ in the present study. In addition, the distances from facial tuberosity to the infra-orbital canal and from the latter to the root of the first upper premolar tooth were $2.91 \pm 0.068 \mathrm{~cm}$ and $3.21 \pm 0.078 \mathrm{~cm}$, respectively. The length and height of the mandible were $42.98 \pm 0.624 \mathrm{~cm}$ and $22.58 \pm 0.287 \mathrm{~cm}$, respectively. Furthermore, the distances from the lateral alveolar root to mental foramen and from the mental foramen to the caudal mandibular margin were $9.22 \pm 0.059 \mathrm{~cm}$ and $32.12 \pm 0.165 \mathrm{~cm}$, respectively. In the present study, the distances from mandibular foramen to the base of the mandible as well as from the caudal margin of mandible to below of the mandibular foramen were $8.84 \pm 0.085 \mathrm{~cm}$ and $6.32 \pm 0.048 \mathrm{~cm}$, respectively. Also, the distances from the base of mandible to fossa condylaris and from the latter to the maximum height of the mandible were $18.38 \pm 0.15 \mathrm{~cm}$ and $4.175 \pm 0.046 \mathrm{~cm}$, respectively. Finally, the distance from the caudal margin of mandible to mandibular foramen and from the latter to mandibular angle were $5.88 \pm 0.055 \mathrm{~cm}$ and $8.29 \pm 0.079 \mathrm{~cm}$, respectively. The morphometric information provided in this study will be important for clinical maneuvers around the head of the Indian native camels particularly for the regional anesthesia during treating head injury and dental extraction.

KEY WORDS: Applied anatomy; Maxillofacial; Mandibular; Camel; Regional anesthesia.

\section{INTRODUCTION}

One-humped camel (Camelus dromedarius) is found in India, Iran, Iraq, Arabia, Egypt, Sudan, North Africa, Somaliland and many other countries. This animal adapted to the rigorous climate of the desert where it is subjected to high temperature and the scorching sun rays. Generally, camels are experiencing a resurgence of interest and their importance in the modern era may depend in great part to the complete understanding of their anatomy and physiology. The head is a very important region for animals. It is the location of vital organs as the brain, eyes, nose, tongue, ear and mouth. Also, the health of an animal can be deduced from the functional state of any of these organs (Olopade \& Onwuka, 2003). Additionally, a unique head aspect of the anatomy of any animal is the skull typology of that animal with usefulness in providing a database of the bone features (Olopade \& Onwuka, 2003). The regional anatomy of the head is therefore, a very useful tool that will aid the regional anesthesia (Olopade \& Onwuka, 2007). For instance, Choudhary et al., (2015b)

\footnotetext{
Assistant Professor. Department of Veterinary Anatomy and Histology, College of Veterinary Sciences and Animal Husbandry, Central Agricultural University, Selesih, Aizawl, Mizoram- 796014, India.

** Associate Professor and Head, Department of Veterinary Anatomy and Histology, College of Veterinary Sciences and Animal Husbandry, Central Agricultural University, Selesih, Aizawl, Mizoram- 796014, India.
} 
CHOUdHARY, O. P.; KALITA, P. C.; KALITA, A. \& DOLEY, P. J. Applied anatomy of the maxillofacial and mandibular regions of the Indian one-humped camel (Camelus dromedarius) and its clinical implications during regional anesthesia. Int. J. Morphol., 34(3) 968-974, 2016.

determined the applied landmarks of the head region of the Indian Blackbuck and their application to clinical maneuvers around the head. The present work was carried out because of there is a lack of comprehensive data on the head region of the adult one-humped camel and its clinical implications during regional anesthesia.

\section{MATERIAL AND METHOD}

This study involved some morphometric parameters of the maxillas and mandibles of six adults Indian Onehumped camels (Camelus dromedarius) without any apparent skeletal disorders. A total of twenty one morphometric measurements were done in the maxilla and mandibles using scale, thread and digital calipers and the results were presented as means $\pm \mathrm{SD}$ in Table I.
The various parameters measured in the upper and lower jawbones of the skull of Indian one humped camel are described below and shown in Figures 1-4.

A. Skull Length: From the dorsal lateral nasal cartilages to the external occipital protuberance; sub-divided into cranial length (A1) and nasal length (A2).

B. Skull width: Maximum distance between two zygomatic arches.

C. Skull/cephalic index (SI): Skull width/Skull length X 100 (Miller et al., 1964).

D. Supraorbital foramen distance: Greatest width between the supraorbital foramen.

E. Infraorbital foramen distance: Facial width between the supraorbital foramen.

F. Facial tuberosity to the infra-orbital canal: From the level of the most lateral bulging of the facial tuberosity to the mid level of the infra-orbital canal.

Table I.The measurements of maxilla and mandibles of Indian One-Humped Camel (Camelus dromedarius)

\begin{tabular}{|c|c|c|}
\hline Sr. No. & Different Parameters & Mean \pm SD \\
\hline \multirow[t]{3}{*}{ A. } & Skull length & $48.75 \pm 0.244$ \\
\hline & Cranial length (A1) & $32.73 \pm 0.484$ \\
\hline & Nasal length (A2) & $16.89 \pm 0.283$ \\
\hline B. & Skull width & $22.66 \pm 0.108$ \\
\hline C. & Skull/cephalic index & $46.51 \pm 0.29$ \\
\hline D. & Supraorbital foramina distance & $6.35 \pm 0.047$ \\
\hline E. & Infraorbital foramina distance & $8.41 \pm 0.076$ \\
\hline F. & Facial tuberosity to the infra-orbital canal & $2.19 \pm 0.068$ \\
\hline G. & Infra-orbital canal to the root of alveolar tooth & $3.21 \pm 0.078$ \\
\hline H. & Distance between supraorbital foramina and infraorbital foramina & $4.485 \pm 0.046$ \\
\hline I. & Distance between orbital rim to supraorbital foramina & $5.66 \pm 0.051$ \\
\hline J. & Distance between orbital rim to infraorbital for amina & $5.87 \pm 0.053$ \\
\hline $\mathrm{K}$. & Lateral alveolar root to mental foramen & $9.22 \pm 0.059$ \\
\hline L. & Mental foramen to the caudal mandibular border & $32.12 \pm 0.165$ \\
\hline M. & Mandibular length & $42.98 \pm 0.624$ \\
\hline N. & Mandibular height & $22.58 \pm 0.287$ \\
\hline $\mathrm{O}$. & Mandibular foramen to base of mandible & $8.84 \pm 0.085$ \\
\hline P. & Caudal border of mandible to below mandibular foramen & $6.32 \pm 0.048$ \\
\hline Q. & Condyloid fossa to the height of the mandible & $4.175 \pm 0.046$ \\
\hline R. & Condyloid fossa to the base of the mandible & $18.38 \pm 0.15$ \\
\hline S. & Caudal border of mandible to the level of mandibular foramen & $5.88 \pm 0.055$ \\
\hline $\mathrm{T}$. & Mandibular foramen to mandibular angle & $8.29 \pm 0.079$ \\
\hline
\end{tabular}


G. Infra-orbital canal to the root of alveolar tooth: The measurement was taken vertically from the mid-level of the infra-orbital canal to the root of the alveolar tooth.

H. Distance between supraorbital foramen and infraorbital foramen.

I. Distance between orbital rim to infraorbital foramen.

J. Lateral alveolar root to mental foramen: From the mental foramen to the lateral extent of the alveolar root of lower incisor.

K. Mental foramen to the caudal mandibular margin: From the level of the mental foramen to the extreme caudal margin of the mandible.

L. Mandibular length: From the level of the cranial extremity of the alveolar root of the incisor to the level of the caudal margin of the mandible.

M. Maximum mandibular height: From the basal level of the mandible to the highest level of the coronoid process.

N. Mandibular foramen to base of mandible: Vertical line from the ventral limit of the mandibular foramen to the base of the mandible.

O. Caudal margin of mandible to below mandibular foramen: Length from the caudal most margin of the mandible to the vertical line produced by a description of the measurement of the mandibular foramen to the base of the mandible.

P. Fossa condylaris to the height of the mandible: From the maximum height of mandible to the fossa condylaris.

Q. Fossa condylaris to the base of the mandible.

R. Caudal margin of mandible to the level of mandibular foramen.

S. Mandibular foramen to mandibular angle: Shortest distance from the mandibular foramen to the extreme caudal margin of the angle of the mandible.

T. Height and width of the supraorbital foramen.

These parameters of the mandible were measured and subjected to routine statistical analysis (Snedecor \& Cochran, 1994).

\section{RESULTS AND DISCUSSION}

In the present study, the supraorbital foramen distance, infraorbital foramen distance, skull length, skull width, cranial length and nasal length of the Indian onehumped camels were $6.35 \pm 0.047 \mathrm{~cm}, 8.41 \pm 0.076 \mathrm{~cm}$, $48.75 \pm 0.244 \mathrm{~cm}, 22.66 \pm 0.108 \mathrm{~cm}, 32.73 \pm 0.484 \mathrm{~cm}$ and $16.89 \pm 0.283 \mathrm{~cm}$, respectively (Fig. 1, Table I). However, the supraorbital foramen distance, infraorbital foramen distance, skull length, cranial length and nasal length were $18.3 \mathrm{~cm}, 6.43 \mathrm{~cm}, 46.2 \mathrm{~cm}, 32.5 \mathrm{~cm}$ and $13.3 \mathrm{~cm}$, respectively in the Iranian one-humped camels. Zhu et al. (2014) also reported skull length, skull width and cranial length in

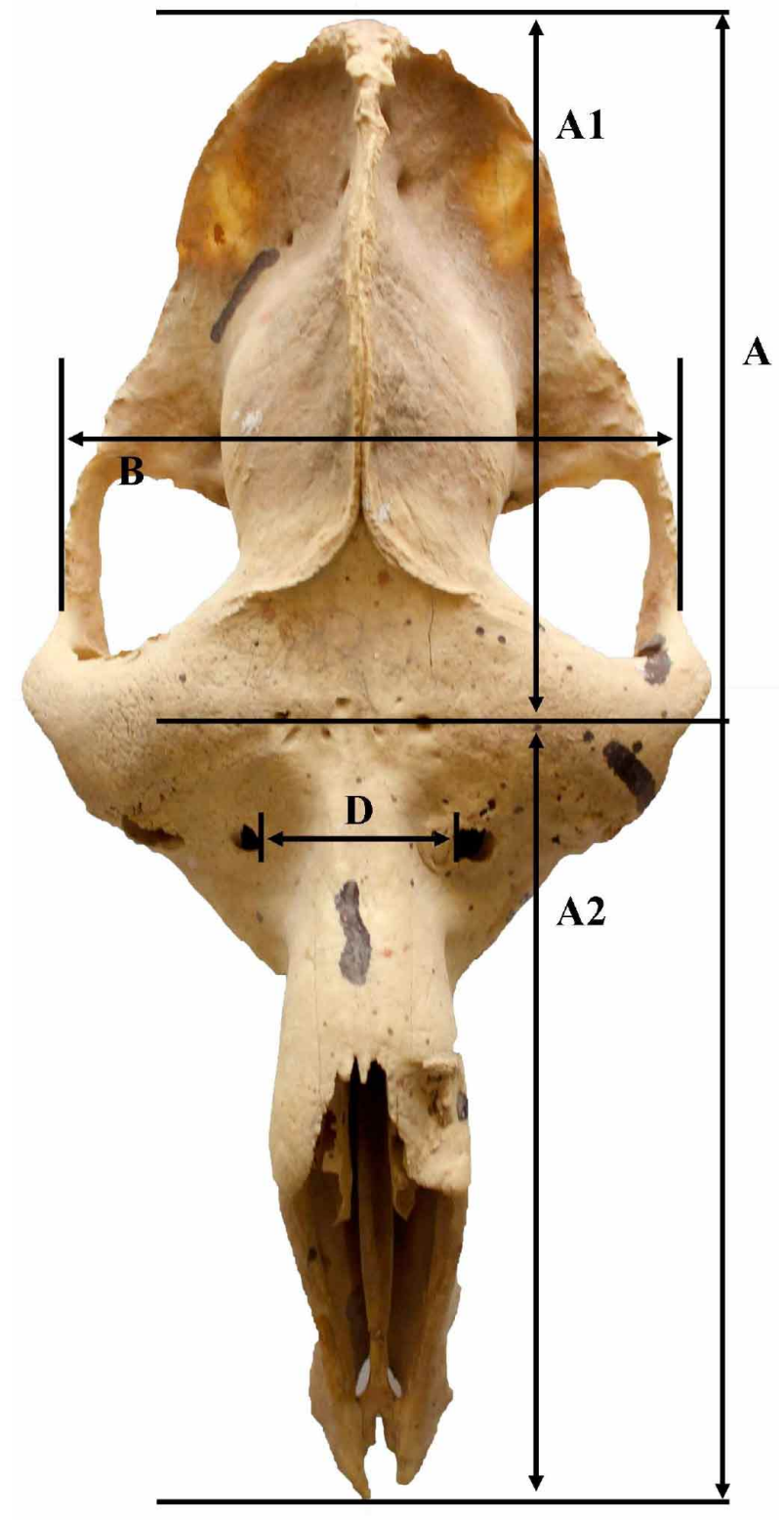

Fig. 1. Measurements of the Skull of Indian one-humped camel showing skull length (A), cranial length (A1), nasal length (A2), width of skull (B), distance between supraorbital foramen (D).

donkey were $44.307 \pm 5.35 \mathrm{~cm}, 16.90 \pm 1.76 \mathrm{~cm}$ and $20.782 \pm 2.22 \mathrm{~cm}$, respectively.

The values of supraorbital foramen distance, skull length, cranial length and nasal length of the Indian native camels were relatively higher than the results obtained from the immature one-humped camel in Nigeria (Yahaya et al., 2012). It is may be due to the existence of significant differences in the some skull's morphometric indices between adult and young animals. 


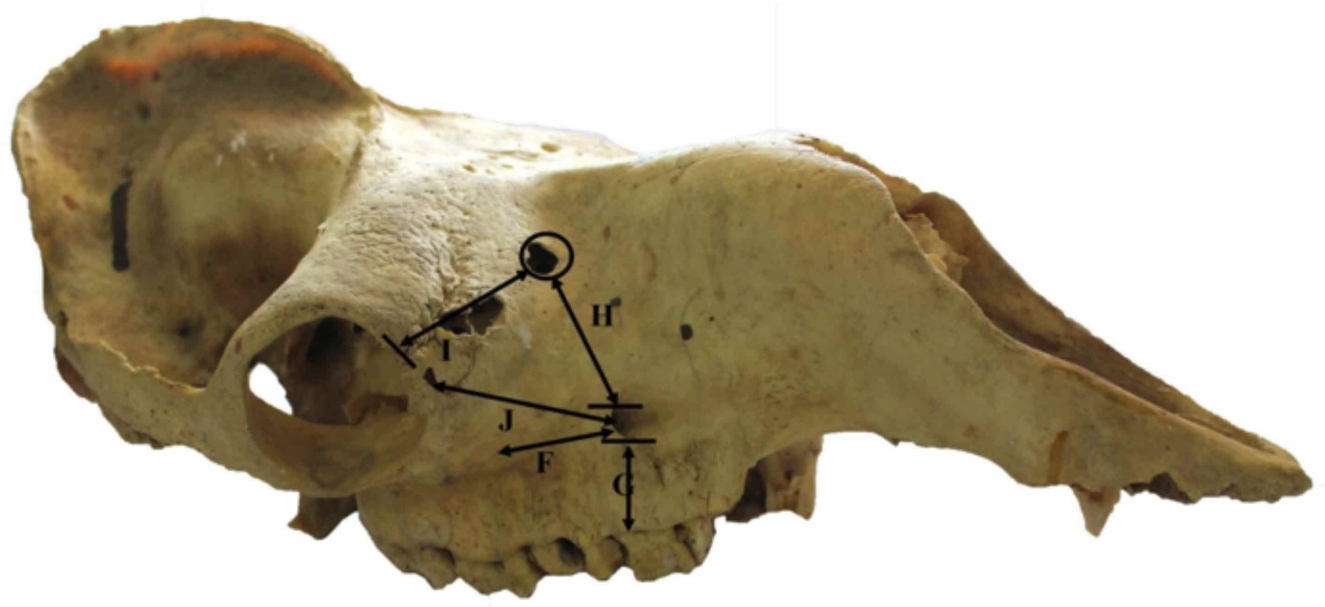

Fig. 2. Measurements of the skull of Indian onehumped camel showing distance between facial tuberosity to the infraorbital canal $(\mathrm{F})$, infraorbital canal to the root of alveolar tooth (G), distance between supraorbital foramen to infraorbital foramen $(\mathrm{H})$, supraorbital foramen to rim of orbit (I), infraorbital foramen to rim of orbit (J).

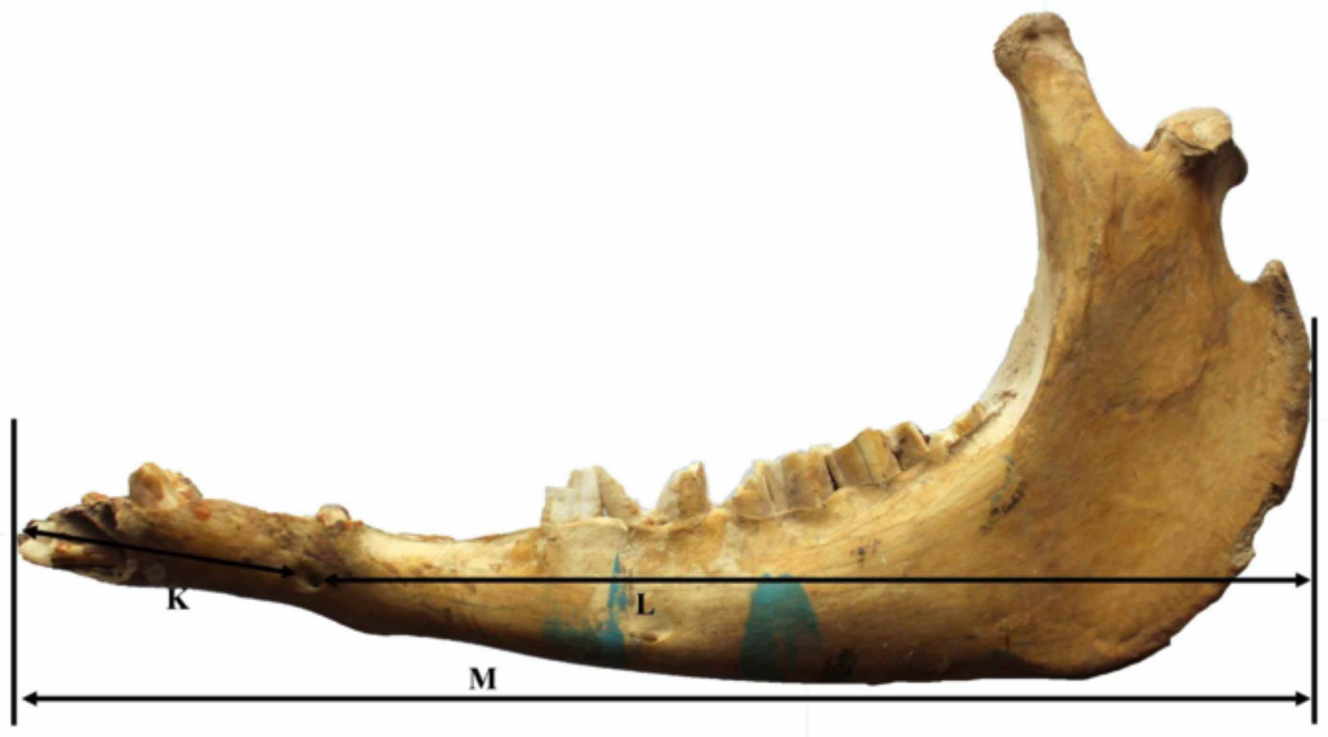

Fig. 3. Measurements of the mandible showing distance from lateral alveolar root to mental foramen $(\mathrm{K})$, mental foramen to the caudal mandibular margin $(\mathrm{M})$, mandibular length $(\mathrm{N})$.

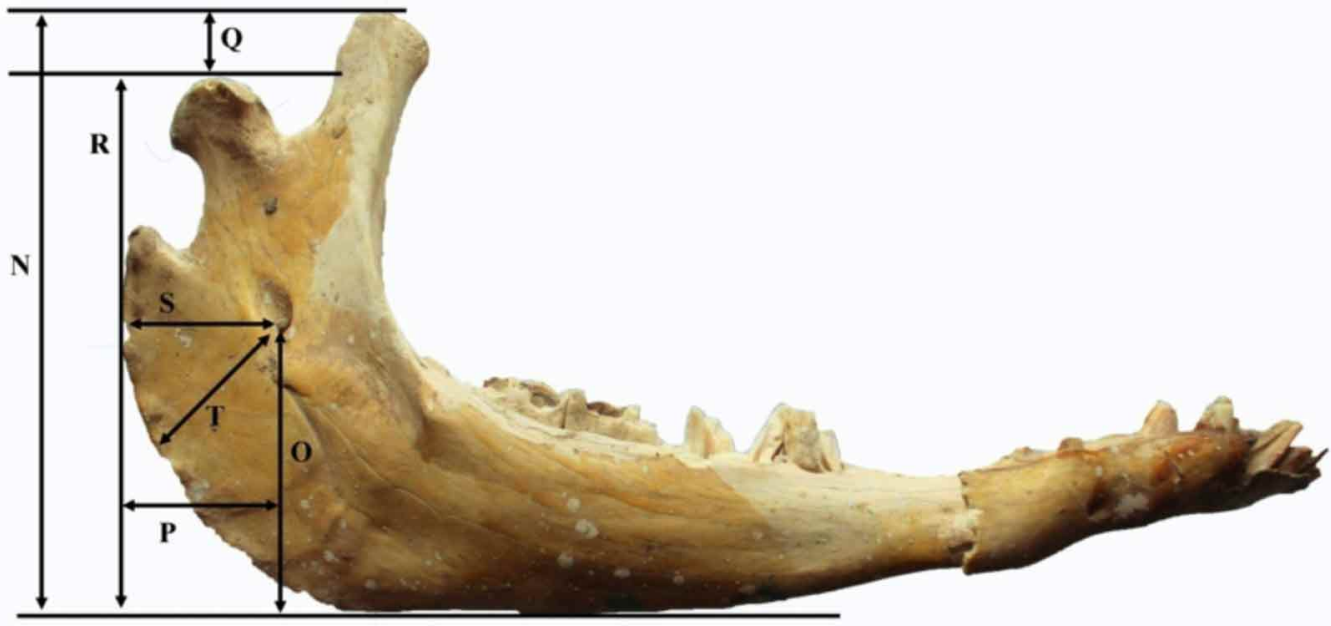

Fig. 4. Measurements of the mandible showing maximum mandibular height $(\mathrm{N})$, distance from mandibular foramen to base of mandible $(\mathrm{O})$, caudal margin of mandible to below mandibular foramen $(\mathrm{P})$, fossa condylaris to height of mandible $(\mathrm{Q})$, fossa condylaris to the base of the mandible (R), caudal margin of mandible to the level of mandibular foramen (S), mandibular foramen to mandibular angle (T). 
The distance between supraorbital foramen and infraorbital foramen was $4.485 \pm 0.046 \mathrm{~cm}$, while the distance between the rim of the orbit to the supraorbital foramen and infraorbital foramen was $5.66 \pm 0.051 \mathrm{~cm}$ and $5.87 \pm 0.053 \mathrm{~cm}$, respectively in Indian one-humped camel.

The skull index was $46.51 \pm 0.29 \mathrm{~cm}$ in Indian onehumped camel, whereas it was $38.23 \pm 0.85 \mathrm{~cm}$ in donkey (Zhu et al.,) and $46.12 \pm 0.12 \mathrm{~cm}$ in blackbuck (Choudhary \& Singh, 2015b).

The distance from the facial tuberosity to the infraorbital canal and from the latter to the root of the alveolar tooth directly ventral to it (Fig. 1) were $2.19 \pm 0.068 \mathrm{~cm}$ and $3.21 \pm 0.078 \mathrm{~cm}$, respectively in camel (Table I) while in West African Dwarfs goats were 1.6-1.8 $\mathrm{cm}$ and 1.3$1.6 \mathrm{~cm}$ (Olopade \& Onwuka, 2005); in Gwembe Valley dwarf goat were $2.06 \pm 0.14 \mathrm{~cm}$ and $1.13 \pm 0.11 \mathrm{~cm}$ (Kataba et al., 2014); in Iranian native cattle were $2.8 \mathrm{~cm}$ and 2.5 $\mathrm{cm}$ (Monfared, 2013b) and in blackbuck were 2.37 \pm 0.009 $\mathrm{cm}$ and $0.72 \pm 0.008 \mathrm{~cm}$ (Choudhary \& Singh, 2015a). Uddin et al., (2009) also reported same measurements for Black Bengal goat were $1.85 \pm 0.14 \mathrm{~cm}$ and $1.75 \pm 0.19 \mathrm{~cm}$.

The data are of clinical importance because the facial tuberosity is very prominent even in live animals as a guide for tracking the infra-orbital nerve, and necessary for its desensitization during the manipulations in the skin of the upper lip, nostril and face at the level of the foramen. The injection of local anesthetic agents within the canal via the infra-orbital foramen will also lead to analgesia of the incisor, canine and first two premolar teeth.

The distance between the lateral end of the alveolus of the third incisor tooth to the mental foramen was $9.22 \pm 0.059 \mathrm{~cm}$ in Indian one-humped camel (Fig. 2, Table I) which is an important landmark for achieving the location of the mental nerve for the regional nerve block in blackbuck, while it was $1.6 \pm 0.22 \mathrm{~cm}$ in West African Dwarf goat (Olopade \& Onwuka, 2005), $2.0 \pm 0.3 \mathrm{~cm}$ in Red Sokoto (Maradi) goat (Olopade \& Onwuka, 2007), 4.74 $\mathrm{cm}$ in Iranian one-humped camels (Monfared, 2013a) and $2.45 \pm 0.008 \mathrm{~cm}$ in blackbuck (Choudhary \& Singh, 2015a).

In the anterior aspect of the mandibular canal, injection can be made through the mental foramen to desensitize mental aspect of the mandibular nerve. This will ensure the loss of sensation of the lower incisors, premolar and lower lip on that side (Hall et al., 2000). The distance from the mental foramen to the caudal mandibular margin was $32.12 \pm 0.165 \mathrm{~cm}$. However the distance from the mental foramen to the caudal mandibular margin was $13.43 \pm 0.081 \mathrm{~cm}$ in Iranian onehumped camels (Monfared, 2013a).

The length and height of the mandible were $42.98 \pm 0.624 \mathrm{~cm}$ and $22.58 \pm 0.287 \mathrm{~cm}$, respectively in camel which was higher than the value obtained for West African Dwarfs goats of Nigeria as $12.00 \pm 1.89 \mathrm{~cm}$ and $6.90 \pm 1.09 \mathrm{~cm}$, respectively (Olopade \& Onwuka, 2005). However the length and height of the mandible were 27.4 $\mathrm{cm}$ and $15.88 \mathrm{~cm}$ in Iranian native cattle; $39.9 \mathrm{~cm}$ and 9.92 $\mathrm{cm}$ in Iranian one-humped camels (Monfared, 2013a) and $16.53 \pm 0.128 \mathrm{~cm}$ and $10.69 \pm 0.024 \mathrm{~cm}$ in blackbuck (Choudhary et al., 2015b).

The distances between the fossa condylaris to the height of mandible and fossa condylaris to the base of the mandible were $4.175 \pm 0.046 \mathrm{~cm}$ and $18.38 \pm 0.15 \mathrm{~cm}$, respectively in camel. Whereas, the distances between the fossa condylaris to the height of mandible and fossa condylaris to the base of the mandible were $3.09 \pm 0.008$ $\mathrm{cm}$ and $7.57 \pm 0.024 \mathrm{~cm}$, respectively in blackbuck (Choudhary \& Singh, 2015a).

The distance between the vertical line drawn downward from the caudal margin of mandible (R) and the vertical line drawn from the mandibular foramen downwards (O) was (P) $6.32 \pm 0.048 \mathrm{~cm}$ (Fig. 3), while same distance was observed $1.85 \pm 0.011 \mathrm{~cm}$ in blackbuck (Choudhary \& Singh, 2015a).

The distances from the mandibular foramen to the base of the mandible, caudal margin of mandible to the level of mandibular foramen and the mandibular foramen to the margin of mandibular angle were $8.84 \pm 0.085$ $\mathrm{cm}, 5.88 \pm 0.055 \mathrm{~cm}$ and $8.29 \pm 0.079 \mathrm{~cm}$ respectively (Fig. 4). However, the distances from the mandibular foramen to the base of the mandible, caudal margin of mandible to the level of mandibular foramen and the mandibular foramen to the margin of mandibular angle were $4.18 \pm 0.014 \mathrm{~cm}, 1.36 \pm 0.010 \mathrm{~cm}$ and $3.07 \pm 0.006 \mathrm{~cm}$, respectively in blackbuck (Choudhary \& Singh, 2015a). These parameters are clinically important landmarks that will aid in the administration of regional anesthesia of the mandibular nerve, for desensitization of all the teeth in the lower jaw on the side of the block (Hall et al.,). Equivalent figures for West African Dwarfs goats of Nigeria were $1.57 \pm 0.44 \mathrm{~cm}, 2.58 \pm 0.34 \mathrm{~cm}$, respectively, for the caudal margin of mandible to below mandibular foramen and the mandibular foramen to the base of the mandible (Olopade \& Onwuka, 2005). In horse and dogs the distance between the mandibular foramen and the base of the mandible was $3 \mathrm{~cm}$ and 1.5 to $2 \mathrm{~cm}$, respectively for (Hall et al.,). 
CHOUdHARY, O. P.; KALITA, P. C.; KALITA, A. \& DOLEY, P. J. Applied anatomy of the maxillofacial and mandibular regions of the Indian one-humped camel (Camelus dromedarius) and its clinical implications during regional anesthesia. Int. J. Morphol., 34(3) 968-974, 2016.

\section{CONCLUSIONS}

This study involved some osteometric parameters of the maxillas and mandibles of six adults Indian one-humped camels without any apparent skeletal disorders. Then, a total of twenty one head measurements and indices were recorded in the present study. The morphometric information provided in this study will be important for clinical maneuvers around the head of the Indian native camels particularly for the regional anesthesia during treating head injury and dental extraction.

CHOUDHARY, O. P.; KALITA, P. C.; KALITA, A. \& DOLEY, P. J. Anatomía aplicada de las regiones maxilofaciales y mandibulares del camello jorobado (Camelus dromedarius) de la India y sus implicaciones clínicas durante la anestesia regional. Int. J. Morphol., 34(3):968-974, 2016.

RESUMEN: Dada la ausencia completa de datos sobre anatomía aplicada de la región de la cabeza del camello jorobado de la India y debido a su valor clínico durante la anestesia regional, este estudio fue diseñado para proporcionar información clínica importante sobre los parámetros de la región de la cabeza. Este estudio incluyó algunos parámetros osteométricos del maxilar y las mandíbulas de seis camellos adultos indios de una joroba sin aparentes trastornos del esqueleto. Se registró un total de 21 medidas en la cabeza e índices fueron incluídos en el estudio. La distancia del foramen supraorbitario, forámenes infraorbitarios, la longitud del cráneo, el ancho de cráneo, la longitud craneal, la longitud nasal y el ancho del cráneo de los camellos jorobados fueron de 6,35 $\pm 0,047 \mathrm{~cm}, 8,41 \pm 0,076 \mathrm{~cm}$, $48,75 \pm 0,244 \mathrm{~cm}, 22,66 \pm 0,108 \mathrm{~cm}, 32,73 \pm 0,484 \mathrm{~cm}$ y $16,89 \pm 0,283 \mathrm{~cm}$, respectivamente. El índice del cráneo fue 46,51 $\pm 0,29 \mathrm{~cm}$. Las distancias de tuberosidad facial del canal infraorbitario a la raíz del primer diente premolar superior fueron de 2,91 $\pm 0,068 \mathrm{~cm}$ y 3,21 $\pm 0,078 \mathrm{~cm}$, respectivamente. La longitud y la altura de la mandíbula fueron $42,98 \pm 0,624 \mathrm{~cm}$ y 22,58 $\pm 0,287 \mathrm{~cm}$, respectivamente. Por otra parte, las distancias desde la raíz alveolar lateral al foramen mental y desde el foramen mental al margen mandibular caudal fueron $9,22 \pm 0,059 \mathrm{~cm}$ y $32,12 \pm 0,165 \mathrm{~cm}$, respectivamente. Las distancias del foramen mandibular a la base de la mandíbula, así como del margen caudal de la mandíbula por debajo del foramen mandibular fueron $8,84 \pm 0,085 \mathrm{~cm}$ y $6,32 \pm 0,048 \mathrm{~cm}$, respectivamente. También, las distancias desde la base mandibular a la fosa condilar, y desde este último a la altura máxima de la mandíbula fueron $18.38 \pm$ $0.15 \mathrm{~cm}$ y $4.175 \pm 0.046 \mathrm{~cm}$, respectivamente. Por último, la distancia desde el margen caudal de la mandíbula al foramen mandibular, y de este al ángulo mandibular fueron 5,88 $\pm 0,055 \mathrm{~cm}$ y 8,29 $\pm 0,079 \mathrm{~cm}$, respectivamente. La información morfométrica proporcionada en este estudio será importante para las maniobras clínicas en la cabeza de los camellos indios, en particular para la anestesia regional durante el tratamiento de lesiones en la cabeza y en la extracción dental.

PALABRAS CLAVE: Anatomía aplicada; Maxilofacial; Mandibular; Camello; Anestesia regional.

\section{REFERENCES}

Choudhary, O. P. \& Singh, I. Applied anatomy of the maxillofacial and mandibular regions of the Indian blackbuck (Antilope cervicapra). J. Anim. Res., 5(3):497-500, 2015a.

Choudhary, O. P. \& Singh, I. Morphometrical studies on the skull of Indian Blackbuck (Antelope cervicapra). Int. J. Morphol., 33(3):868-76, 2015b.

Choudhary, O. P.; Singh, I.; Bharti, S. K.; Mohd, K. I.; Sathapathy, S. \& Mrigesh, M. Gross and morphometrical studies on mandible of blackbuck (Antelope cervicapra). Int. J. Morphol., 33(2):428-32, 2015a.

Choudhary, O. P.; Singh, I.; Bharti, S. K.; Mohd, K. I.; Dhote, B. S. \& Mrigesh, M. Clinical anatomy of head region of Indian Blackbuck. Indian Vet. J., 92(3):59-62, 2015b.
Hall, L. W.; Clarke, K. W. \& Trim, C. M. Wright's Veterinary Anaesthesia and Analgesia. $10^{\text {th }}$ ed. London, ELBS and Baillierre Tindall, 2000.

Kataba, A.; Mwaanga, E. S.; Simukoko, H. \& Parés, C. P. M. Clinical anatomy of the head Region of Gwembe Valley dwarf goat in Zambia. Int. J. Vet. Sci., 3(3):142-6, 2014.

Monfared, A. L. Applied anatomy of the head regions of the onehumped camel (Camelus dromedarius) and its clinical implications during regional anesthesia. Glob. Vet., 10(3):322-6, 2013a.

Monfared, A. L. Gross anatomical measurements of the head region of the iranian native cattle (Bos taurus) and their clinical value for regional anesthesia. Glob. Vet., 10(2):219$22,2013 b$. 
CHOUdHARY, O. P.; KALITA, P. C.; KALITA, A. \& DOLEY, P. J. Applied anatomy of the maxillofacial and mandibular regions of the Indian one-humped camel (Camelus dromedarius) and its clinical implications during regional anesthesia. Int. J. Morphol., 34(3) 968-974, 2016.

Olopade, J. O. \& Onwuka, S. K. A preliminary investigation into some aspects of the craniofacial indices of the Red Sokoto (Maradi) goat in Nigeria. Folia Vet., 47(2):57-9, 2003.

Olopade, J. O. \& Onwuka, S. K. Some aspects of the clinical anatomy of the mandibular and maxillofacial regions of the West African dwarf goat in Nigeria. Int. J. Morphol., 23(1):336, 2005.

Olopade, J. O. \& Onwuka, S. K. Osteometric studies of the skull of red sokoto (Maradi) goats (Capra hircus): Implications for regional anaesthesia of the head. Int. J. Morphol., 25(2):407-10, 2007.

Snedecor, G. W. \& Cochran, W. G. Statistical Methods. $8^{\text {th }}$ ed. Ames, Iowa State University Press, 1994.

Uddin, M. M.; Ahmed, S. S. U.; Islam, Kh. N. \& Islam, Md. M. Clinical anatomy of the head region of the black bengal goat in Bangladesh. Int. J. Morphol., 27(4):1269-73, 2009.

Yahaya, A.; Olopade, J. O.; Kwari, H. D. \& Wiam, I. M. Osteometry of the skull of one-humped camels. Part I: immature animals. Ital. J. Anat. Embryol., 117(1):23-33, 2012.

Zhu, L.; Shi, X. D.; Wang, J. J. \& Chen, J. G. A morphometric study on the skull of donkey (Equus asinus). Int. J. Morphol., 32(4):1306-10, 2014.

\author{
Correspondence to: \\ Dr. O.P. Choudhary \\ Assistant Professor \\ Department of Veterinary Anatomy and Histology \\ College of Veterinary Sciences and Animal Husbandry \\ Central Agricultural University \\ Selesih, Aizawl, Mizoram- 796014 \\ INDIA
}

\section{Email:dr_om_choudhary@yahoo.co.in dr.om.choudhary@gmail.com}

Recibido : 02-01-2016
Aceptado:18-07-2016 